\title{
Enric Bou, La invenció de l'espai. Ciutat i viatge, València, Publicacions de la Universitat de València, 2013, 332 pp.
}

L'espai ha estat generalment abordat, en les aproximacions analítiques, com l’àmbit de l'objectivitat prèviament donada: un conjunt de dades externes al subjecte que el contempla, el conceptualitza, el descriu o l'habita. En especial, com a contrapartida d'un subjecte que l'observa davant per davant. Així, la dialèctica subjecte/objecte es configurava com un dualisme simplificat. I és que la seva materialitat aparentment incòlume confereix a l'espai una consistència objectual de la qual no disposa, pel seu costat, el temps, molt més difícil d'aprehendre en el seu fluir.

En efecte, comprenem facilment que el temps travessa existències personals i que el subjecte configura el (seu) temps des de la percepció interior del jo. Bergson, entre altres, va ocupar-se del tema des de l'angle filosòfic. La lingüística cognitiva, per la seva banda, traça processos de subjectivització on la representació espacial precedeix la temporal, de manera que el temps tendeix a ser concebut en termes d'espai, perquè l'espai és més tangible i, per tant, té més opcions d'esdevenir domini originari disposat a projectar-se metafòricament sobre un domini meta desconegut i abstracte. En efecte, el temps passa o corre, s'escapa, es contempla en la llunyania o ens arriba de manera sobtada. Moltes vegades, doncs, ha de ser visualitzat a través d'un espai tridimensional per on, metafòricament, es desplaça.

També en la literatura l'espai és més primari que el temps. Les teories de la novel.la, per exemple, s'han ocupat amb deler de la temporalitat com a dimensió representativa que dóna joc per a l'anàlisi: el tempo lento, l'analepsi o flash-back, la prolepsi, la manipulació temporal que ordeix la intriga... L'espai, en canvi, ha estat la parenta pobra que, a tot estirar, s'associa a una època en l'amalgama del cronòtop bakthinià. D'aquesta manera, l'espai esdevé l'àmbit de la descripció, de l'estatisme, enfront de la dimensió temporal, que és el moll de l'os del relat o el motor que l'engega.

Però vet aquí que són nombroses les veus que en anys recents han reivindicat l'interès de l'espai, que deixa de ser un contenidor inert per esdevenir un agent de la significació. Diríem que la dada externa al subjecte es concep més aviat com una realitat construïda, en el marc d'una teorització constructivista. I qui diu construïda, diu inventada, tal com ho expressa el títol del llibre de Bou. Per a Bou, l'espai —els espais, els llocs- és un autèntic agent provocador: provocador de sentits, exactament. El capítol que dedica en el seu llibre als rius i als mapes és d'una lucidesa admirable. Bou hi fa parlar els "accidents geogràicss", que esdevenen personatges de la representació sociocultural, bé en els mapes que els configuren com a signes gràfics, bé en la 
literatura que els utilitza emocionalment. Rius, muntanyes, fronteres o ponts assoleixen entitat semiòtica en una original cartografia de les significacions. I sovint el fenomen afecta unes representacions gràfiques (per exemple, els mapes delimitadors d'un país al llarg de la història) que poden constituir autèntics constructes ideològics.

Ara bé, el moll de l'os de la invenció de l'espai és la ciutat (urbs com a espai físic configurat per edificis i carrers, civitas com a col-lectivitat d'habitants, i polis com a entitat politicoadministrativa). La ciutat és el lloc de la modernitat, del caos postmodern, de l'activació de les relacions socials i de la creativitat artística. Configura identitats col-lectives i condensa la història en els seus estrats com un dipòsit geològic o un palimpsest. Òbviament, darrere d'aquestes consideracions intuïm les reflexions de Walter Benjamin, o les d'un Michel de Certeau, l'inventor de la vida quotidiana. Hi ressonen les passes del flâneur que deambula sense objectiu fix, contempla els carrers, les cases, les façanes, els aparadors o l'àgora, tot vivint la ciutat des de dins, amb una autenticitat superior a la que es deriva d'una panoràmica aèria despersonalitzada.

La ciutat esdevé així un text, llegible i susceptible de ser prolongat amb nous relats que el van refent. Els escriptors (i les escriptores, és clar) han contribuït a la construcció socioimaginària de moltes ciutats. Dickens, Sue, Baudelaire, Lorca, Joyce, Durrell, Estellés... són autors que es vinculen en un moment o altre a ciutats reals que refan imaginàriament amb llur escriptura. Enric Bou, posseïdor d'una cultura amplíssima i mancat absolutament de prejudicis provincians, es mou amb desimboltura per tota aquesta cartografia de referències literàries, on fa algunes esplèndides aturades en les quals fa palesa la funció de la literatura "com a arma de construcció massiva». Són objecte de les seves anàlisis, des d'aquesta perspectiva, el Bearn de Villalonga, La plaça del Diamant de la Rodoreda o les novel.les barcelonines d'Eduardo Mendoza. Són obres on assistim de la representació d'identitats urbanes que la literatura contribueix a dissenyar des del seu observatori-laboratori.

Les pàgines del llibre dedicades a aquests temes traspuen erudició - lectures històriques i literàries, i inquietuds teòriques—, però no defugen reflexions de fons, més enllà de la panòplia de les modes crítiques. Les pàgines són denses de referències especialitzades i d'estudiosos d'aquesta temàtica (Gaston Bachelard, Richard Lehan, Pierre Nora, Joan Ramon Resina, Edward Soja, Raymond Williams...), però tambéens sorprenen amb flaixos d'idees fresques a cada cantonada de l'itinerari. D'altra banda, Bou disposa de bones fonts d'antropologia i de sociologia, però descarrega el pes de l'atenció sobre la literatura, que li forneix continguts d'estudi, materials documentals i formes artístiques. Dit breument: entre les guies turístiques típiques o els treballs de geografia urbana i, de l'altre cantó, l'obra literària, hi ha la distància d'un plus a favor d'aquesta darrera: l'elaboració d'un estil que potencia els efectes de sentit. Aquesta 
defensa de la funcionalitat del discurs literari s'hi expressa amb mots de Ricoeur: «La littérature est à la fois un amplificateur et un analyseur des ressources de sens disponibles dans l'usage ordinaire de la langue commune.».

Però no tot és la ciutat. Hi ha també els viatges — els desplaçament a llargues distàncies_- als quals es dediquen els darrers capítols del volum. Els viatgers, tant si són exploradors aventurers com si són turistes massificats, busquen, a través de l'espai, un exotisme que contraposar a la realitat quotidiana d'on parteixen. Aquest viatjar presenta, en diversos sentits, una vinculació estreta amb l'escriure, amb la voluntat de deixar constància escrita de l'experiència viscuda i de la transformació interior que el viatger experimenta.

D’una banda, hi ha la guia turística, la modelització esquemàtica i esbiaixada del lloc visitat, un text que informa, descriu, orienta i aconsella. El gènere suscita avui un intens interès als analistes del discurs, que hi veuen una construcció semiòtica complexa, impregnada d'ideologia, que alimenta l'imaginari col-lectiu. I no oblidem que hi ha guies turístiques «cultes», fins i tot il.lustrement literàries, que van més enllà de la seva utilitat pragmàtica, com ara El País Valenciano de Joan Fuster o la resta de volums de la col-lecció de l'editorial Destino que l'acollia. Si molt estirem el concepte, encara trobem obres poètiques com el Canto general de Neruda o el Mural del País Valencià d'Estellés que tenen alguna cosa —o molta cosa — de magnes catàlegs que inciten els visitants forans a la contemplació poètica i que elaboren una representació essencial de la identitat col-lectiva d'un poble.

De l'altra banda, hi ha els llibres de viatges, on un autor narra la seva peripècia aventurera, les descobertes que fa en primera persona. Si bé es mira, el llibre de viatges relata generalment unes transformacions del jo en el seu camí vital, i per això mateix reclama una certa escriptura dietarística que fa del viatger un escriptor i que, del viatge, en fa text: literatura del jo al capdavall. Bou, que ja va publicar anys enrere un sucós llibre sobre la literatura del jo, examina aquí el cas dels viatges a l'URSS (la descoberta més aviat negativa del paradís comunista), o als impersonals no-llocs del supermercat o l'autopista (d'acord amb la tediosament difosa conceptualització de Marc Augé). Però a més d'aquestes visites a prosaics països d'enlloc, l'autor dedica pàgines plenes d'acuïtat al tema etern de l'exili, tan antic com el Gènesi, però tan viu, sobretot en la memòria del desenllaç de la Guerra Civil espanyola. Així s'esdevé amb els exiliats republicans a França o a països llatinoamericans, on, en el cas del catalans, podien viure el doble exili de la terra i de la llengua. I, com a estació final del viacrucis, un retorn que podia constituir el xoc descoratjador d'un nou exili en el lloc que ja no era el seu. L'exemple del retorn de Max Aub, tal com ell mateix el textualitza en La gallina ciega, és prodigiosament expressiu d'aquest desengany que indueix novament la sensació de desterrament. 
Enric Bou ha aplegat en La invenció de l'espai. Ciutat i viatge un munt de suggestions incitadores. Ni tan sols les errates tipogràfiques que apareixen sobretot en els darrers capítols entorpeixen la lectura plaent i engrescadora d'aquesta proposta teoricoanalítica que es consolida com a referència essencial en el marc de la semiòtica literària i cultural. Explorador de fronteres ell mateix, l'autor ofereix als lectors un vertader breviari de pensaments lluminosos i un quadern de bitàcola útil per navegar a través d'aquests capítols de la cultura actual que un dia foren perifèrics però que avui conciten l'interès de molts habitants de diverses parcel-les del pensament, literatura inclosa.

Vicent Salvador

Universitat Jaume I vicent.salvador@fil.uji.es 